\title{
PROGRAM INFOTAINMENT DITINJAU DARI ETIKA KOMUNIKASI ISLAM (Analisis terhadap Insert Siang di TRANS TV Edisi Bulan Ramadhan 1437 H)
}

\author{
Yesi Ristiana \\ Jurusan Komunikasi dan penyiaran islam UIN Walisongo \\ yesiristiana@gmail.com
}

\begin{abstract}
$P$ ublic interest on television made media industry competing for the attention of viewer, such as infotainment shows. In practice infotainment shows a lot of controversy. But in Ramadhan, usually media television expressly competing to produce and publish religious programs. This study aims to describe how Insert Siang infotainment program in Trans TV Ramadhan $1437 \mathrm{H}$ edition in term of Islamic Comunication Ethic. In this case refers to the theory of Jalaluddin Rakhmat about the ethics of Islamic. By using content analysis, the result show that: not all information in Insert Siang are good content. 82\% infotainment that exposed in Ramadhan shows that news served with Islamic Communication ethic. According to Jalaluddin Rakhmat, in six form, there are qaulan sadidan 14\%, qaulan balighan 18\%, qaulan kariman 11\%, qaulan ma'rufan 18\%, qaulan layyinan 7\%, and qaulan maysuran $14 \%$.
\end{abstract}

Keyword: Television, infotainment, Ramadhan, Islamic Communication Ethic.

\begin{abstract}
ABSTRAK
$\mathrm{B}$

esarnya animo publik terhadap televisi mengakibatkan industri media berlomba merebut perhatian pemirsa dengan beragam tayangan menarik, seperti infotainment. Dalam praktiknya tayangan infotainment banyak menuai kontroversi. Namun pada bulan Ramadhan, umumnya televisi dengan sengaja berlomba memproduksi dan menayangkan program yang bermuatan religi. Penelitian ini bertujuan untuk mendeskripsikan bagaimana program infotainment Insert Siang di Trans TV edisi bulan Ramadhan 1437 H ditinjau dari etika komunikasi Islam. Dalam hal ini mengacu pada teori dari Jalaluddin Rakhmat tentang Etika Komunikasi Islam. Dengan menggunakan konten analisis, diperoleh hasil: tidak semua informasi dalam program infotainment Insert Siang bermuatan baik. Sebesar $82 \%$ dariberita hiburan yang ditayangkan di bulan Ramadhan menunjukkan beritanya disajikan sesuai dengan etika komunikasi Islam merujuk konsepnya Jalaluddin Rakhmat, yang menyebut enam (6) bentuk, qaulan sadidan 14\%, qaulan balighan 18\%, qaulan kariman 11\%, qaulan ma'rufan 18\%, qaulan layyinan 7\%, dan qaulan maysuran $14 \%$.
\end{abstract}

Kata kunci: Televisi, infotainment, Ramadhan, etika komunikasi Islam.

$100 \mid \begin{aligned} & \text { Islamic Comunication Journal } \\ & \text { Volume 02, nomor 1, Januari-Juni } 2017\end{aligned}$ 


\section{PENDAHULUAN}

Pada era modern seperti ini, keberagaman media massa semakin berkembang dan bervariatif jenisnya, hal tersebut merupakan bukti nyata pesatnya teknologi informasi. Era globalisasi telah menyuguhkan kemudahan akses informasi yang dibutuhkan dalam hitungan detik dengan biaya yang relatif murah, sekian banyak peristiwa yang ada di jagat raya ini dengan cepatnya diberitakan. Menurut Burhan Bungin dalam buku Media Relations Konsep, Strategi \& Aplikasi, media massa ialah media komunikasi dan informasi yang melakukan penyebaran informasi secara massal dan dapat diakses oleh masyarakat secara massal pula. Secara umum media massa mempunyai fungsi yaitu menyiarkan informasi, mendidik, menghibur dan mempengaruhi.

Belakangan kebutuhan setiap individu untuk mendapatkan informasi diperoleh dari media massa semakin pesat, dimulai dari media cetak seperti surat kabar, majalah dan buku kemudian disusul media elektronik seperti radio, televisi bahkan sekarang muncul jaringan internet. Salah satu media massa yang efektif untuk menyampaikan informasi adalah televisi karena dapat memadukan suara dan gambar (audiovisual), sekarang ini pun tidak dipungkiri mayoritas masyarakat Indonesia mempunyai televisi di rumahnya sebagai media untuk memperoleh informasi sekaligus hiburan.

Besarnya animo publik terhadap televisi membuat industri media bersaing merebut perhatian pemirsa dengan bermacam acara yang dianggap memiliki nilai lebih dibandingkan media lain. Banyak tayangan menarik yang disajikan demi mengalihkan perhatian publik. Mulai dari berita, sinetron, kuis, infotainment, sampai realitas buatan yang disulap menjadi fakta objektif.

Maraknya tayangan infotainment ini kental dipengaruhi kuatnya logika pasar bebas yang dikendalikan oleh kepentingan pasar. Hiburan menjadi dasar ideologi bagi segala konten yang disajikan di televisi karena orientasinya ialah untuk menjaring rating sebesar-besarnya. Dipublikasikan dalam data highlights Nielsen Newsletter edisi 14-28 Februari 2011 penonton tv setia terhadap program informasi (seperti dokumenter, majalah TV, infotainment, hobi, gaya hidup, dsb) meningkat di Februari sebanyak 61\%. Salah satu faktor yang menyebabkan maraknya tayangan infotainment di layar kaca adalah murahnya biaya produksi jenis program ini, di sisi lain minat para pengiklan masih lumayan tinggi dengan dibuktikan penuhnya slot iklan berbagai program infotainment.

Namun dalam prakteknya, tayangan infotainment di televisi banyak menuai kontroversi dari berbagai kalangan seperti tokoh masyarakat, LSM, dan bahkan dari kalangan jurnalistik karena ada yang mempertanyakan keabsahannya sebagai kegiatan jurnalistik, dan ada pula yang mempersoalkan konten tayangan yang dianggapnya telah kebablasan. Pers memang harus diberi keleluasaan dan kebebasan dalam mencari dan menyiarkan informasi ke masyarakat. Namun demikian pers tidak lantas bebas melainkan terikat dengan etika profesi yang melingkupinya,

\section{Islamic Comunication Journal Volume 2, Nomor 1, Januari-Juni 2017


yakni etika jurnalistik. Etika ini disusun sebagai cita ideal sekaligus mengatur dan mengarahkan wartawan dalam menjalankan aktivitasnya. Etika jurnalistik ini menjadi standar moral dan etis bagi wartawan dan praktisi pers yang harus diperhatikan dan ditaati.

Terlepas dari kontroversi bermanfaat tidaknya tayangan infotainment, sudah selayaknya pekerja infotainment khususnya harus lebih berfikir jernih dan harus lebih arif menerima berbagai masukan dari semua unsur masyarakat, terlebih lembaga resmi dengan satu prinsip, semua untuk kepentingan publik dengan mengedepankan prinsip hidup saling menghargai.

Meskipun media memiliki kebebasan, namun tidak dapat terlepas dari tanggungjawab. Oleh karena itu yang dibutuhkan media adalah jujur (qawlan sadidan) yang berarti berkata atau menyampaikan informasi dengan jujur, seperti salah satu prinsip yang telah dikemukakan oleh Jalaluddin Rakhmat dalam prinsip etika komunikasi Islamnya. Kejujuran dalam mengumpulkan data, mengolah dan menyajikan berita, sehingga memahami tentang etika dalam jurnalistik. Media yang dengan mudah tergoda untuk memperuncing fakta-fakta dengan menghilangkan sebagian berita, memfokuskan suatu detail yang kecil tetapi menyentil, atau dengan memancing kutipankutipan yang provokatif, yang tujuannya bukanlah untuk mengatakan suatu kebenaran melainkan untuk menarik perhatian, media seperti inilah yang melanggar etika, baik etika dalam jurnalistik sekaligus etika komunikasi Islam itu sendiri.

Persaingan antar program infotainment, mengharuskan pemilik media dituntut kreatif dalam menyuguhkan tayangan infotainment yang selalu mempunyai inovasi. Banyak sekali stasiun televisi yang menyajikan program infotainment, mulai dari Insert siang di TRANS TV, Silet di RCTI dan KISS di Indosiar dan masih banyak yang lainnya. Namun yang menarik bagi penulis yaitu program acara Insert siang di TRANS TV. Insert (Informasi Selebritis), merupakan andalan TRANS TV dan cikal bakal adanya tayangan infotainment Insert pagi, Insert up date dan Insert investigasi.

Rating yang tinggi untuk tayangan infotainment menunjukkan bahwa acara ini merupakan salah satu acara infotainment favorit pemirsa tanah air. Data dari Hedi dalam bukunya Menelisik Lika-Liku Infotainment di Media Televisi, menyebutkan proporsi jumlah tayangan infotainment terbanyak terdapat pada TRANS TV, stasiun ini mempunyai jumlah tayangan infotainment sebanyak 27 kali dalam satu minggu.(Hendi Pujo, 2011:114)

"Insert Siang" dengan slogan "Where Gossip Can Be Fun!" ini tayang setiap hari Senin-Jum'at pukul 13.00 WIB, Sabtu \& Minggu pukul 11.30 WIB yang berdurasi 60-70 menit dengan pembawa acara yang berganti setiap harinya seperti Indra Herlambang, Lenna Tan, Andry Danu, Fenita Arie, Marissa Nasution. Insert siang memiliki kekuatan di inovasi konten yang beragam diantaranya dengan adanya segmen "insert news hi lite" yang 
merupakan rangkuman berita singkat seputar selebritis Indonesia, "top sert" di akhir pekan yang berisi poling berita yang diminati selama sepekan, "selebritis on vacation" yang berisi kisah perjalanan para artis saat berlibur di berbagai tempat baik dalam maupun luar negeri, "seleb versus" merupakan membandingkan dua selebriti bisa dari segi prestasi, gaya hidup, tampang, popularitas dan sebagainya, "selebiriti infashion" mengenai penampilan para selebritis dimana akan mendapat komentar dan mendapatkan saran dari salah satu ahli fashion stylish Indonesia, serta yang terbaru ialah sesi "tanya dokter" yang mana para selebritis bebas bertanya seputar kesehatan kepada dokter yang sudah stand by di studio TRANS TV.

Berawal dari latar belakang tersebut, ketika MUI, NU mengeluarkan fatwa bahwa Infotainment yang kontennya bersifat ghibah itu haram. Meskipun begitu, jika dilihat dari sudut pandang yang berbeda, infotainment juga mempunyai sisi baik meskipun itu tertutupi dengan sisi buruk yang lebih dominan dengan ghibah yang sudah melekat pada infotainment. Tidak bisa dipungkiri juga, di lain pihak acara infotainment sangat digemari oleh masyarakat, karena jam penayangan yang setiap hari sehingga membuat pertumbuhannya semakin menjamur di industri pertelevisian Indonesia. Pengemasan informasi yang ringan dengan penyajian yang santai dan menghibur seakan membuat infotainment tidak terpisahkan dari kehidupan masyarakat luas dan menjadi candu bagi pemirsa yang menyaksikan tayangan infotainment.
Terlebih lagi program infotainment saat edisi bulan Ramadhan, dalam pemberitaannya lebih mengarah ke suatu hal yang bersifat positif, mengandung banyak nilai-nilai Islami seperti halnya pemberitaan terkait selebritis tanah air yang bersedekah kepada anak yatim piatu, bagibagi takjil, dan cenderung pemberitaannya minim dengan ghibah. Melihat hal demikian, jangan mengabaikan fakta positif yang ada meskipun dalam program infotainment sudah melekat banyak hal yang negatif.

Berangkat dari fenomena tersebut, maka timbullah pertanyaan dari benak penulis yaitu bagaimana jadinya jika pemberitaan dalam program infotainment Insert siang TRANS TV ditinjau dari kaca mata etika komunikasi Islam, apakah nantinya akan terdapat enam prinsip etika komunikasi Islam seperti yang diungkapkan oleh Jalaluddin Rakhmat, dalam program infotainment Insert siang di TRANS TV dalam proses memberitakan, menginformasikan, menayangkan program tersebut?

\section{ETIKA KOMUNIKASI ISLAM}

Sebelum penulis membahas tentang etika komunikasi Islam, hendaknya perlu diketahui terlebih dahulu pengertian dari komunikasi Islam itu sendiri. Menurut A. Muis dalam bukunya Komunikasi Islami memaparkan bahwa semua macam komunikasi Islam pada dasarnya tidak berbeda dengan komunikasi non-Islam dalam hal model, proses dan efeknya, tetapi yang membedakannya lebih kepada landasan filosofisnya. Landasan filosofis 
komunikasi Islam ialah Al-Qur'an dan Hadis Nabi. Jadi komunikasi Islam adalah proses penyampaian pesan antar manusia didasarkan pada ajaran agama Islam yang terkandung dalam al-Qur'an dan Hadis.

Etika komunikasi Islam kurang lebih sama juga dengan etika komunikasi umum. Isi perintah dan larangan sama atau serupa antara keduanya. Adapun menurut Tata Taufik dalam bukunya Etika Komunikasi Islam mengungkapkan bahwa dakwah merupakan komunikasi Islam dimana dakwah dan komunikasi sebagai suatu teknik, serta dakwah Islamiah sebagai tindakan amar ma'ruf nahi munkar serta penyampaian pesan risalah Islamiah.(Tata Taufik, 2012 :211)

Selanjutnya etika komunikasi Islam yang telah dipaparkan oleh Jalaluddin Rakhmat dalam bukunya Islam Aktual: Refleksi Sosial Seorang Cendekiawan Muslim ialah ada enam bentuk atau jenis gaya bicara (qawlan) di dalam al-Qur'an yang dikategorikan sebagai kaidah, prinsip atau etika komunikasi Islam. Bentuk-bentuk etika komunikasi Islam tersebut seperti halnya (Jalaluddin Rakhma,1994 :76)

\section{a. Qawlan Sadidan (perkataan yang benar)}

Kata qawlan sadidan disebut dua kali dalam Al-Qur'an.Pertama, Allah menyuruh manusia menyampaikan qawlan sadidan dalam urusan anak yatim dan keturunan, terdapat dalam Firman Allah QS. An-Nisaa: 9

$104 \mid \begin{aligned} & \text { Islamic Comunication Journal } \\ & \text { Volume 02, nomor 1, Januari-Juni } 2017\end{aligned}$

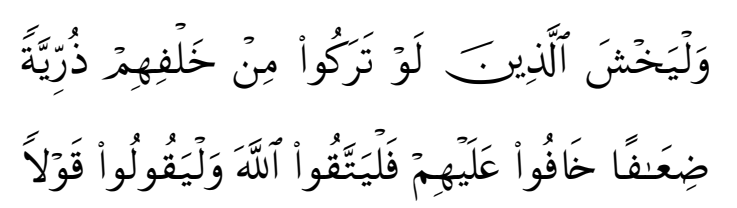

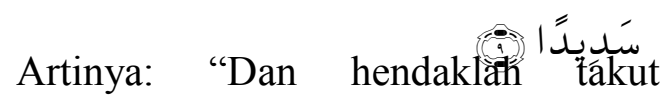
(kepada Allah) orang-orang yang mereka sekiranya meninggalkan keturunan yang lemah di belakang mereka yang mereka khawatir terhadap (kesejahterahan)nya. Oleh sebab itu, hendaklah mereka bertakwa kepada Allah, dan hendaklah mereka berbicara dengan tutur kata yang benar".

Kedua, Allah memerintahkan qawlan sadidan sesudah taqwa. Hal tersebut dalam FirmanNya QS. Al-Ahzaab: 70

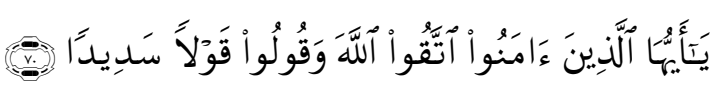

Artinya: "Wahai orang-orang yang beriman! Bertakwalah kamu kepada Allah dan ucapkanlah perkataan yang benar".

Prinsip komunikasi yang pertama menurut Al-Quran adalah berkata yang benar. Ada beberapa makna dari pengertian yang benar :

1) Sesuai dengan kriteria kebenaran

Arti pertama benar adalah sesuai dengan kebenaran. Dalam segi substansi mencakup faktual, tidak direkayasa atau dimanipulasi. Sedangkan dari segi redaksi, harus menggunakan kata-kata yang baik dan benar, baku dan sesuai dengan kaidah bahasa yang berlaku.

2) Tidak bohong

Arti kedua dari qawlan sadidan adalah ucapan yang jujur, tidak bohong 
dapat diwujudkan dengan menjaga lisan. Nabi Muhammad saw bersabda:

"Dari Abu Juhaifah, Rasulullah Saw bertanya: "amal apa yang paling disukai Allah? para sahabat terdiam. Tidak seorang pun menjawab. Kemudian, beliau sendiri menjawab dengan bersabda; Menjaga Lisan”. (Alaik, 2011: 98)

\section{b. Qawlan Baligha (efektif, tepat sasaran)}

Kata "baligh" dalam bahasa arab artinya sampai, mengenai sasaran atau mencapai tujuan. Apabila dikaitkan dengan qawl (ucapan atau komunikasi), "baligh" berarti fasih, jelas maknanya, terang, tepat mengungkapkan apa yang dikehendaki. Oleh karena itu prinsip qawlan baligha dapat diterjemahkan sebagai prinsip komunikasi yang efektif.

Secara terperinci, ungkapan qawlan baligha dapat dilihat dalam QS. An-Nisaa: 63

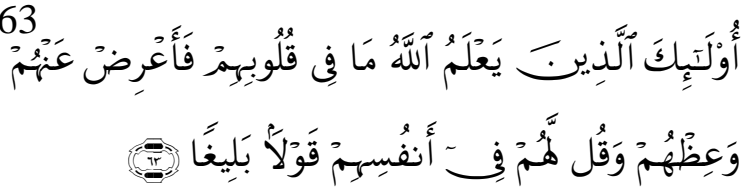

Artinya: "Mereka itu adalah orangorang yang (sesungguhnya) Allah mengetahui apa yang ada di dalam hatinya. Karena itu berpalinglah kamu dari mereka, dan berilah mereka nasihat, dan katakanlah kepada mereka perkataan yang membekas pada jiwanya".

Lebih jauh penafsiran dari ayat di atas adalah mengibaratkan hati mereka sebagai wadah ucapan, dan wadah tersebut harus diperhatikan. Sehingga apa yang dimaksudkan ke dalamnya sesuai, bukan saja dalam kuantitasnya, tetapi juga dengan sifat dari wadah tersebut. Dalam hal ini, ada jiwa yang harus diasah dengan ucapanucapan halus, dan ada pula yang harus dientakkan dengan kalimat-kalimat yang keras atau ancaman yang menakutkan. Pada akhirnya, di samping ucapan yang disampaikan, cara penyampaian dan waktunya pun harus diperhatikan.

Jalaluddin Rahmat memerinci pengertian qawlan baligha menjadi dua, qawlan baligha terjadi bila da'i (komunikator) menyesuaikan pembica raannya dengan sifat-sifat khalayak yang dihadapinya sesuai dengan frame of reference and field of experience. Kedua, qaulan baligha terjadi bila komunikator menyentuh khalayaknya pada hati dan otaknya sekaligus. Jika dicermati dapat disimpulkan kata qawlan baligha ialah menggunakan kata-kata yang efektif, tepat sasaran, komunikatif, mudah dimengerti, langsung ke pokok masalah (straight to the point), dan tidak berbelit-belit atau berteletele. Agar komunikasi tepat sasaran, gaya bicara dan pesan yang disampaikan hendaklah disesuaikan dengan kadar intelektualitas komunikan dan menggunakan bahasa yang dimengerti oleh mereka.

c. Qawlan Karima (perkataan yang mulia)

Perkataan yang mulia, dibarengi dengan rasa hormat dan mengagungkan, enak didengar, lemah-lembut, dan bertata krama. Jika dikaji lebih jauh, komunikasi dakwah dengan menggunakan qawlan karima lebih ke sasaran dengan tingkatan umurnya lebih tua. Sehingga, pendekatan yang digunakan lebih pada pendekatan yang sifatnya pada sesuatu yang santun, lembut, 
dengan tingkatan dan sopan santun yang diutamakan. Dalam artian, memberikan penghormatan dan tidak menggurui dan retorika yang berapi-api.

Terkait dengan hal tersebut, ungkapan qawlan karima ini terdapat dalam QS. AlIsraa: 23

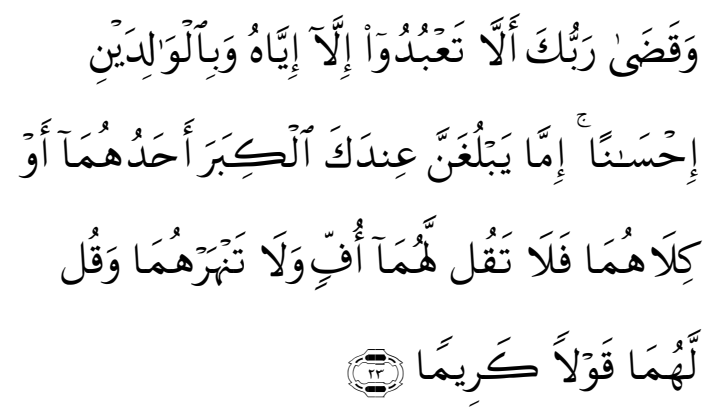

Artinya: "Dan Tuhanmu telah memerintahkan agar kamu jangan menyembah selain DIA dan hendaklah berbuat baik kepada ibu-bapak. Jika salah seorang diantara keduanya atau keduaduanya sampai berusia lanjut dalam pemeliharaanmu, maka sekali-kali janganlah engkau mengatakan kepada keduanya perkataan 'ah' dan janganlah engkau membentak keduanya, dan ucapkanlah kepada keduanya perkataan yang baik".

Dengan penjelasan diatas maka qawlan karima diperlakukan jika dakwah itu ditujukan kepada kelompok orang yang sudah masuk kategori usia lanjut. Seseorang $d a ' i$ dalam perhubungan dengan lapisan mad'u yang sudah masuk kategori usia lanjut, haruslah bersikap seperti terhadap orang tua sendiri, yakni hormat dan tidak kasar kepadanya, karena manusia meskipun telah mencapai usia lanjut, bisa saja berbuat salah atau melakukan hal-hal yang sesat menurut ukuran agama.

Komunikasi yang baik tidak dinilai dari tinggi rendahnya jabatan atau pangkat seseorang, tetapi ia dinilai dari perkataan seseorang. Cukup banyak orang yang gagal berkomunikasi dengan baik kepada orang lain disebabkan mempergunakan perkataan yang keliru dan berpotensi merendahkan orang lain. Permasalahan perkataan tidak bisa dianggap ringan dalam komunikasi. Karena salah perkataan berimplikasi terhadap kualitas komunikasi dan pada gilirannya mempengaruhi kualitas hubungan sosial. Bahkan karena salah perkataan hubungan sosial itu putus sama sekali.

\section{d. Qawlan Ma'rufan (perkataan yang} baik, pantas)

Ungkapan qawlan ma'rufan, jika ditelusuri lebih dalam dapat diartikan dengan "ungkapan atau ucapan yang pantas dan baik". "pantas" di sini juga bisa diartikan sebagai kata-kata yang "terhormat", sedangkan "baik" diartikan sebagai kata-kata yang "sopan".

Qawlan Ma'rufan juga bermakna pembicaraan yang bermanfaat dan menimbulkan kebaikan. Sebagai muslim yang beriman, perkataan kita harus terjaga dari perkataan yang sia-sia, apapun yang kita ucapkan harus selalu mengandung nasehat, menyejukkan hati bagi orang yang mendengarnya. Jangan sampai kita hanya mencari-cari kejelekan orang lain, yang hanya bisa mengkritik atau mencari kesalahan orang lain, memfitnah dan 
menghasut. Ungkapan qawlan ma'rufan terungkap dalam QS. An-Nisaa: 8

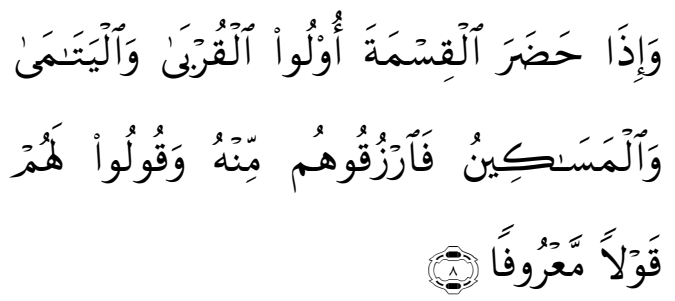

Artinya: "Dan apabila sewaktu pembagian itu hadir beberapa kerabat, anakanak yatim dan orang-orang miskin, maka berilah mereka dari harta itu (sekedarnya) dan ucapkanlah kepada mereka perkataan yang baik".

Ayat tersebut menjelaskan bahwa, qawlan ma'rufan adalah perkataan yang baik. Allah menggunakan frase ini ketika berbicara tentang kewajiban orang-orang kaya atau kuat terhadap orang-orang miskin atau lemah. Qawlan ma'rufan berarti pembicaraan yang bermanfaat memberikan pengetahuan, mencerahkan pemikiran, menunjukkan pemecahan terhadap kesulitan kepada orang lemah, jika tidak dapat membantu secara material, setidaknya dapat membantu secara psikologi.

\section{e. Qawlan Layyina (lemah lembut)}

Qawlan Layyina berarti pembicaraan yang lemah-lembut, dengan suara yang enak didengar, dan penuh keramahan, sehingga dapat menyentuh hati maksudnya tidak mengeraskan suara, seperti membentak, meninggikan suara. Siapapun tidak suka bila berbicara dengan orangorang yang kasar. Rasulullah selalu bertutur kata dengan lemah lembut, hingga setiap kata yang beliau ucapkan sangat menyentuh hati siapapun yang mendengarnya.
Perilaku untuk berlaku lemah lembut tersebut tergambar dalam QS. Thaa-haa: 44

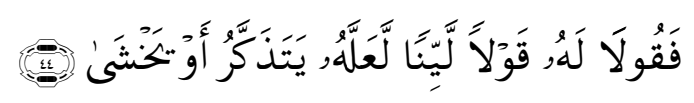

Artinya: "Maka berbicaralah kamu berdua kepadanya (Fir'aun) dengan katakata yang lemah lembut, mudah-mudahan dia sadar atau takut".

Contoh di atas, merupakan salah satu sikap bijak dari Nabi Muhammad SAW yang lemah lembut dalam berdakwah (menyikapi masalah). Dengan demikian, interaksi aktif dari qawlan layyina adalah komunikasi yang ditujukan pada dua karakter mad'u. Pertama, adalah pada mad' $u$ tingkat penguasa dengan perkataan yang lemah lembut menghindarkan atau menimbulkan sifat konfrontatif. Kedua, mad'u pada tataran budayanya yang masih rendah. Sikap dengan qawlan layyina akan berimbas pada sikap simpati dan sebaliknya akan menghindarkan atu menimbulkan sikap antipati.

\section{f. Qawlan Maisura (mudah diterima).}

Dalam Al-Qur'an ditemukan istilah qawlan maisura yang merupakan salah satu tuntunan untuk melakukan komunikasi dengan mempergunakan bahasa yang mudah dimengerti dan melegakan perasaan.(Djamarah, 2004 : 110)

Secara terminologi qawlan maisura berarti "mudah". Lebih lanjut dalam komunikasi dakwah dengan menggunakan qawlan maisura dapat diartikan bahwa dalam menyampaikan pesan dakwah, $d a$ ' $i$ harus menggunakan bahasa yang "ringan", 
"sederhana", "pantas", atau yang "mudah diterima" oleh mad'u secara spontan tanpa harus melalui pemikiran berat. Perkataan qawlan maisura terekam pada QS. Al-Israa: 28

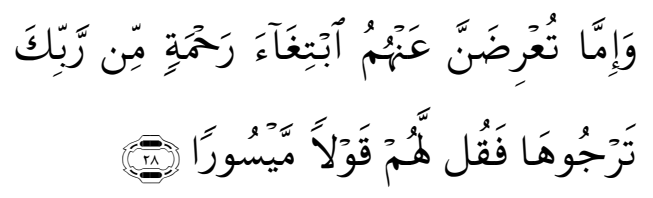

Artinya: "Dan jika engkau berpaling dari mereka untuk memperoleh rahmat dari Tuhanmu yang engkau harapkan, maka katakanlah kepada mereka ucapan yang lemah lembut".

Maksud dari ayat di atas, apabila kamu tidak dapat melaksanakan perintah Allah Swt, maka katakanlah kepada mereka perkataan yang baik agar mereka tidak kecewa lantaran mereka belum mendapat bantuan dari kamu. Oleh karena itu, kamu dapat memberikan kepada mereka hak-hak mereka.

Untuk mempermudah dalam memahami suatu perkataan seperti yang diungkapkan oleh Jalaluddin Rakhmat dari uraian tentang enam prinsip, bentuk, gaya bahasa (qawlan) yang meliputi qawlan sadidan, qawlan baligha, qawlan karima, qawlan ma'rufan, qawlan layyina, qawlan maisura maka dibutuhkan suatu parameter atau indikator sebagai alat ukur atau standarisasi untuk mengetahui kriteria dari masing-masing qawlan tersebut yang terdapat dalam tabel berikut ini:

Tabel Indikator Prinsip Etika Komunikasi Islam (Qawlan)

\begin{tabular}{|c|c|c|c|}
\hline No & Aspek & Arti & Indikator \\
\hline 1. & $\begin{array}{l}\text { Qawlan } \\
\text { Sadidan }\end{array}$ & $\begin{array}{l}\text { Perkataan yang } \\
\text { benar }\end{array}$ & $\begin{array}{l}\text { 1. Sesuai kriteria kebenaran: } \\
\text { a. Segi substansi mencakup faktual, } \\
\text { tidak direkayasa atau dimanipulasi. } \\
\text { b. Segi redaksi menggunakan kata- } \\
\text { kata yang baik, baku, sesuai dengan } \\
\text { kaidah bahasa yang berlaku. } \\
\text { 2. Tidak bohong: ucapan yang jujur } \\
\text { caranya dengan menjaga lisan atau } \\
\text { dalam bertutur kata. }\end{array}$ \\
\hline 2. & $\begin{array}{l}\text { Qawlan } \\
\text { Baligha }\end{array}$ & $\begin{array}{l}\text { Perkataan yang } \\
\text { efektif, tepat sasaran }\end{array}$ & $\begin{array}{l}\text { 1. Adanya frame of reference (referensi } \\
\text { yang sama) } \\
\text { 2. Adanya field of experience (pengalaman } \\
\text { yang sama) } \\
\text { 3. Langsung pada pokok masalah (straight } \\
\text { to the point) } \\
\text { 4. Komunikatif }\end{array}$ \\
\hline 3. & (قَؤلاً كَرِيًْا) & $\begin{array}{l}\text { Perkataan yang } \\
\text { mulia }\end{array}$ & $\begin{array}{l}\text { 1. Bertata krama } \\
\text { 2. Umumnya lebih ke sasaran tingkatan } \\
\text { umur yang lebih tua }\end{array}$ \\
\hline
\end{tabular}

108 \begin{tabular}{l|l} 
Islamic Comunication Journal \\
Volume 02, nomor 1, Januari-Juni 2017
\end{tabular} 


\begin{tabular}{|c|c|c|c|}
\hline No & Aspek & Arti & Indikator \\
\hline & $\begin{array}{l}\text { Qawlan } \\
\text { Karima }\end{array}$ & & $\begin{array}{l}\text { 3. Tidak menggurui } \\
\text { 4. Santun }\end{array}$ \\
\hline 4. & 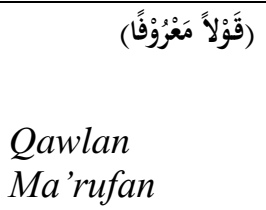 & $\begin{array}{l}\text { Perkataan yang baik, } \\
\text { pantas }\end{array}$ & $\begin{array}{l}\text { 1. Kata-kata sopan } \\
\text { 2. Mengandung nasehat } \\
\text { 3. Menimbulkan kebaikan }\end{array}$ \\
\hline 5. & $\begin{array}{l}\text { Qقَوْلاً لَيَّنًا) } \\
\text { Qawlan } \\
\text { Layyina }\end{array}$ & $\begin{array}{l}\text { Perkataan yang } \\
\text { lemah lembut }\end{array}$ & $\begin{array}{l}\text { 1. Penuh keramahan } \\
\text { 2. Tidak mengeraskan suara } \\
\text { 3. Enak diedengar } \\
\text { 4. Menyejukkan hati }\end{array}$ \\
\hline 6. & 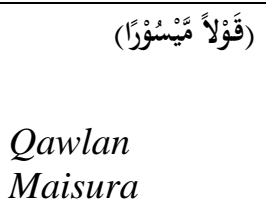 & $\begin{array}{l}\text { Perkataan yang } \\
\text { mudah diterima }\end{array}$ & $\begin{array}{l}\text { 1. Menggunakan bahasa yang mudah } \\
\text { dimengerti } \\
\text { 2. Melegakan perasaan } \\
\text { 3. Sederhana }\end{array}$ \\
\hline
\end{tabular}

\section{ANALISIS ETIKA KOMUNIKASI ISLAM INSERT SIANG DI TRANS TV EDISI BULAN RAMADHAN 1437 H}

Program infotainment di televisi bukan merupakan program Islami, tetapi meskipun begitu jika dikaji lebih lanjut infotainment juga tetap mempunyai sisi baik walaupun tertutupi dengan sisi buruk yang lebih dominan dengan ghibah yang sudah melekat pada infotainment. Pada dalam proses analisis penulis menggunakan etika komunikasi Islam menurut Jalaluddin Rakhmat yang mengemukakan bahwa ada enam bentuk gaya bicara (qawlan) untuk mengetahui bagaimana tinjauan etika komunikasi Islam terhadap infotainment Insert siang di TRANS TV edisi bulan Ramadhan $1437 \mathrm{H}$.

\section{Qawlan Sadidan (perkataan yang benar)}

Jika ditinjau dari qawlan saddidan, ungkapan yang mengandung qawlan sadidan terdapat pada pemberitaan tanggal 5 Juni 2016 pada segmen "Persiapan Selebritis Menyambut Bulan Suci Ramadhan", hal tersebut terlihat saat Krisdayanti melontarkan pernyataan bahwa akan masuk neraka, jika ada segolongan orang yang tidak bahagia ketika menyambut bulan suci Ramadhan.

Dari pernyataan tersebut, penulis mengkategorikan pernyataan Krisdayanti tergolong pada perkataan yang benar, karena ungkapan yang dikatakan telah sesuai dengan indikator yang telah disebutkan pada Tabel diatas, sebelumnya selain itu pernyataan artis tersebut sesuai 
dengan sabda Rasulullah Saw dalam hadis berikut:

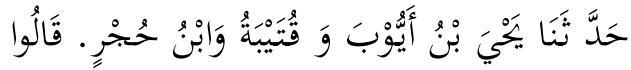

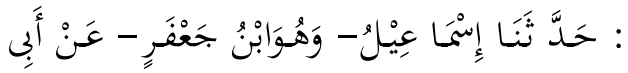

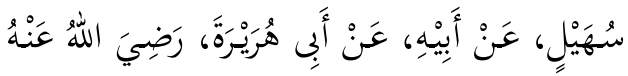

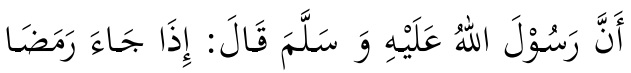

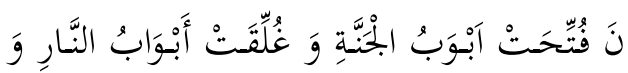

$$
\begin{aligned}
& \text { صُفِّنَ تِ الشَّيَّا طِيْنُ }
\end{aligned}
$$

"Yahya bin Ayyub, Qutaibah, dan Ibnu Hujr menceritakan kepada kami, mereka berkata: Ismail menceritakan kepada kamidia adalan bin Ja'far-dari Abu Suhail, dari ayahnya, dari Abu Hurairah r.a. bahwa Rasulullah Saw telah bersabda: apabila bulan Ramadhan tiba, maka pintu-pintu surga dibuka, pintu-pintu neraka ditutup, dan setan-setan dibelenggu." (HR. Muslim)

Berikut ini adalah cuplikan wawancara dengan KD:

Krisdayanti: “............., saya dengar dan baca jangan biarkan orang yang eeh..tidak bahagia menyambut Ramadhan itu masuk neraka, jadi saya seneng saya termasuk dalam golongan orang-orang yang seneng, bahagia menyambut bulan suci Ramadhan, karena masa sih satu bulan diantara 12 bulan itu bulan Ramadhan, bulan yang terbaik kita gak manfaatkan sebaik-baiknya sih, untuk me-recharge kita menjadi manusia yang baru di fitri."

Kemudian, ungkapan qawlan sadidan juga terdapat pada pemberitaan tanggal 14 Juni 2016 segmen "Hijab Ala Laudya Cintya Bella" dan pada tanggal 1 Juli 2016 segmen "Hobi Menembak Amarzoni". Penulis mengkategorikan kedua pemberitaan tersebut ke dalam perkataan yang benar karena jika ditinjau dari qawlan sadidan dalam memberikan informasi

\section{$110 \mid \begin{aligned} & \text { Islamic Comunication Journal } \\ & \text { Volume 02, nomor 1, Januari-Juni } 2017\end{aligned}$}

terkait sesuatu hal yang berhubungan dengan kehidupan keduanya, mereka tidak merekayasa perkataanya, tidak memanipulasi, dan memang benar faktual sesuai dengan apa yang dialami dan dirasakan oleh keduanya serta sesuai dengan indikator yang terdapat dalam bab sebelumnya.

Hal ini dapat dilihat dari cuplikan wawancara dari kedua selebritis tersebut:

Bella: "ni gayaku sendiri si mbak, aku lebih make sesimpel mungkin karena aku ga begitu suka pake peniti pentul gitu. Aku suka yang pashmina aku lilit-lilit selesai.

Amar: “ Waktu kecil dulu kan sempet diajarin panah juga, main panah pas waktu kecil kan memang sunah ya kalo di Islam gitu kan anak-anak kecil tuh diajarin main panah segala macem jadi ya suka yang berhubungan dengan nembaknembak.

Dari pernyataan keduanya yang menceritakan soal style hijab Bella dan hobi menembak Amarzoni. Bella yang melontarkan tidak terlalu menyukai hijab yang terlalu susah dan tidak nyaman untuk dipakai, sedikit menunjukkan sisi lain Bella setelah berhijrah lebih menyukai busana dan hijab hal yang simpel atau sederhana, sehingga tidak membatasi ruang gerak dari pemakainya. Islam pun, melarang umatnya untuk tidak berlebih-lebihan dalam segala hal, dalam artian dianjurkan mempunyai sikap sederhana dalam segala hal.

Kemudian, dari cuplikan wawancara yang terdapat di dalam pernyataan Amar yang menerangkan bahwa di masa kecilnya dia belajar memanah karena memanah memang salah satu olahraga yang 
dianjurkan atau sunah dalam Islam, sehingga jelas tergambar perkataan yang diucapkan adalah perkataan yang benar.

Kemudian, ungkapan qawlan sadidan juga terdapat pada pemberitaan tanggal 22 Juni 2016 segmen "Intip Media Sosial Chika Jessica". Penulis mengkategorikan pemberitaan tersebut ke dalam qawlan sadidan karena kejadian tersebut benar adanya yaitu postingan Chika yang tengah menirukan gaya salah satu ustadzah di akun instagramnya. Hal tersebut dapat terlihat dari cuplikan video Chika dan juga dari narasi yang diutarakan narator.

Narator: Beberapa tahun terakhir akun pribadi menjadi wadah yang digemari banyak orang, di sana semua perasaan dengan bebas bisa diekspresikan tanpa harus merasa malu apalagi sungkan, karena kebebasan itu mereka mengunggah semua kegiatan mereka dalam berbagai bentuk. Ada yang memposting lewat video dan ada pula yang mengungkapkannya melalui tulisan. Di segmen intip media sosial artis kali ini kami akan mengupas video lucu Chika Jesica berikut komentar dari haters dan lovers dari Chika tentang videonya tersebut. Di akun instagramnya Chika mengunggah video dengan bertausiah menirukan gaya salah seorang ustadzah.

Berikut ini salah satu cuplikan video dubmash Chika yang diunggah dalam akun instagramnya:

Chika: "Karena suami temen Anda centil digodain mulu dia klepek-klepek.. makanya dia merasa gak bersalah, gua gak bersalah..elu yang godain kan. Maap.. itu poin satu."
Narator: Penampilan Chika dengan busana shalat mendapatkan komentar dari para loversnya. 'Samicutes' salah seorang penggemar Chika berkomentar 'hahaha, mama Dedeh ceramah nih'.. yang lain lagi memuji dengan tulisan 'juara dubmash deh pokoknya'.

\section{Qawlan Baligha (fektif, tepat sasaran)}

Jika ditinjau dari qawlan baligha, ungkapan yang mengandung qawlan baligha terdapat pada pemberitaan tanggal 5 Juli 2016 segmen "Jatah Mudik Lebaran Dian Nitami dan Zaskia Mecca". Penulis mengkategorikan pemberitaan ini ke dalam qawlan baligha karena melihat penyataan dari kedua selebriti tersebut dalam mengkomunikasikan kehidupan rumah tangga mereka seperti membagi jatah mudik antara pihak suami dan istri dengan telah sesuai dengan indikator yang ada yaitu komunikatif, tidak berbelit-belit atau tidak bertele-tele, langsung ke pokok masalah.

Berikut ini cuplikan wawancara dengan kedua selebritis yang mengarah pada qawlan baligha:

Dian: "Biasanya iya, dulu waktu ayah ibu saya masih ada biasanya kita gantian tiap tahun untuk lebaran hari pertama jadi kalo orang tua saya kan di Jakarta terus kalo keluarganya Anjas kan di Bandung jadi biasanya satu tahun di Jakarta, satu tahun di Bandung ini nya ya lebaran pertama di Bandung, hari kedua di Jakarta atau sebaliknya hari pertama di Jakarta hari keduanya di Bandung ............."

Zaskia: “..........., Jadi pas awal banget kita nikah, kita lebaran gantian yah kalo tahun ini di Jakarta tahun depan di Jogja lalu

Islamic Comunication Journal Volume 2, Nomor 1, Januari-Juni 2017 
Jakarta, kebetulan tahun lalu di Jogja dan kita punya keluarga yang ketemu cuma pas lebaran yaudah jadi kayak tahun lalu aku gak ketemu keluargaku pas lebaran dan tahun ini gantian."

Kemudian, ungkapan qawlan baligha juga terdapat pada pemberitaan tanggal 15 Juni 2016 segmen "Trend Fashion Hijab Ala Zaskia Sungkar'. Penulis mengkategorikan pemberitaan tersebut ke dalam perkataan yang efektif, tepat sasaran karena jika ditinjau dari qawlan baligha gaya bicara yang disampaikan Zaskia kepada pemirsa komunikatif, mudah dimengerti karena tidak terlalu menggunakan bahasa berbelit-belit sehingga mudah diterima yaitu bisa dikatakan sesuai dengan indikator yang ada.

Berikut ini cuplikan wawancara Zaskia Sungkar:

Zaskia: "Salah satu yang terbaru kayak krudung yang aku pake, terus ini koleksinya..eee..koleksi Ramadhan jadi memang insipirasinya pun dateng dari indonesia. Aku selalu ngembangin critacrita rakyat, trus kain-kain tradisional, pokoknya semua yang berasal dari Indonesia lalu digabungkan dengan cuttingan yang modern atau siluet yang modern. ,

Kemudian, ungkapan qawlan baligha juga terdapat pada pemberitaan tanggal 8 Juni 2016 segmen "Cerita Nycta Gina dan Rizky Kinos Jalani Puasa Pertama Bersama Anak". Penulis mengkategorikan pemberitaan tersebut ke dalam qawlan baligha karena terlihat dari perkataan yang terlontar dari pasangan artis termasuk dalam indikator yang telah disebutkan sebelumnya yaitu keduanya dalam berkomunikasi dengan efektif atau komunikasi yang memang benar-benar dari hati ke hati sehingga saling memahami.

Hal tersebut dapat terlihat dari kutipan wawancara dengan pasangan artis sebagai berikut:

Gina dan Kinos: "Bareng-bareng, pokoknya begitu bangun.. begitu dia harus menyusui ataupun ganti popok berdua bangun. Jadi, dia beres menyusui gitu ada waktu colongan dikit buat sahur..setelah sahur ya temenin dia buat menyusui dan ganti popok gitu."

Melihat kekompakan pasangan artis tersebut dalam mengurus anak, memanglah sangat dibutuhkan komunikasi yang mendalam supaya tidak terjadi kesalahpahaman antara keduanya. Seperti halnya dalam ilmu komunikasi ada istilah komunikasi interpersonal, yaitu komunikasi antara komunikator dengan komunikan yang sifatnya lebih dialogis atau berupa percakapan sehingga lebih efektif.

Kemudian, ungkapan qawlan baligha terdapat pada pemberitaan tanggal 20 Juni 2016 segmen "Putra Jane Shalimar Dapat Penghargaan Penghafal Hadis". Segmen ini memberitakan prestasi yang membanggakan dari putranya Jane Shalimar yang mendapat penghargaan dari sekolahnya sebagai penghafal Hadis. Penulis mengkategorikan pemberitaan tersebut ke dalam qawlan baligha karena melihat komunikasi yang dilakukan Jane dengan putranya Zarno tidak kaku antara keduanya, Jane dalam memberikan pembelajaran dengan menerapkan komunikasi secara tatap muka secara dialogis, saling bertanya satu sama 
lain, komunikatif dan memperlakukan Zarno seperti teman sehingga ada interaksi nyata dan membuat keduanya saling memahami antara satu dengan yang lain dan komunikasi tersebut termasuk dalam indikator pada pembahasan bab sebelumnya.

Hal tersebut dapat terlihat dari kutipan wawancara berikut ini:

Jane: Tapi pas kemarin aku yang dikasih tau gurunya aku yang surprise.. terenyuh juga gitu, dia gak pernah ngasih tau. Biasa dia kan suka malu, trus ayo coba hadisnya gimana...ah malu..hihih. pasti kalau disuruh hafalan sama aku dia malu..kadang-kadang akunya yang terharu, gak nyangka sih..bahwa akan dapet feedback sebegitunya, yang dia tunjukin ke aku..dan akunya jadi uuhh really? Sesuatu yang baru juga buat dia sampai masuk berita, bang no..masuk berita lho, wow..oke,,hahah."

Jane: "Gak boleh males, jadi dia yang ngasih tau aku sih.. jadi pas udah sore, dia udah shalat.. mama kenapa gak sholat? Mama lagi halangan..haha. oh, oke.. apa itu halangan? Ya masalah wanita yang terjadi sebulan sekali..haha. dia sangat kritis, dan aku memang kalau komunikasi sama dia itu gak kayak komunikasi sama anak kecil gitu..jadi ya aku slalu cerita sama dia, sharing sama dia, aku nganggep dia itu temen, dia juga anggep aku kayak temen.. jadi dia kalo cerita entah lagi seneng, kesel, lagi marah atau dia mau cerita dengan nada tinggi aku gak apa-apa, yang penting itu bisa buat dia lepas lah.. biar bisa luapin unek-uneknya gitu."

Selanjutnya, ungkapan qawlan baligha juga terdapat pada pemberitaan tanggal 24 Juni 2016 segmen "Rossa

bahagia Melihat Anak Sukses Berpuasa". Segmen ini memberitakan rasa bahagia sekaligus bangga karena putra semata wayangnya sukses dalam menjalankan ibadah puasa.

Penulis mengkategorikan pemberitaan tersebut ke dalam qawlan baligha karena sudah sesuai dengan indikator yang ada yaitu dengan melihat metode mendidik Rossa pada anaknya tidak menggurui, lebih kepada komunikasi dua arah yang membuat dari sang anak pun merasa nyaman. Dalam mengajari anaknya Rossa juga tidak hanya melulu menyuruh dengan perkataan tetapi langsung mencontohkan, mempraktekkan dengan mengaplikasikan pada perbuatan, sikap sehari-hari sehingga secara otomatis anak juga akan meniru perbuatan yang dicontohkan oleh orang tuanya.

Hal tersebut dapat terlihat dalam kutipan wawancara dengan Rossa sebagai berikut:

Rossa: "Anakku kan ngeliat ya, jadi ya ngeliat aja kalo ibunya puasa ya pasti anaknya ikut puasa. Ibunya shalat ya anaknya insyaAllah ikut shalat.. alhamdulillah udah dari dua tahun lalu udah full,............ buat aku itu bukan sesuatu yang harus dibesar-besarkan, itu memang kewajiban jadi dia tanpa diiming-imingi juga tau..ohh, itu kewajiban saya untuk puasa."

Rossa: “....................Dia bisa hafal apa ya banyak banget.. bisa sampe 22,26 ayat udah biasa dia. Alhamdulillah bahagia, saya seneng banget karena memang sengaja menyekolahkan Rizky di sekolah Islamic gitu ya..setidaknya saya yang tidak bisa mengajari banyak tentang agama tapi dia bisa dapet di sekolah juga." 


\section{Qawlan Karima (Perkataan Yang Mulia)}

Jika ditinjau dari qawlan karima, ungkapan yang mengandung perkataan yang mulia terdapat pada pemberitaan tanggal 20 Juni 2016 segmen "Janji Dimas Beck pada Orang Tua", hal tersebut terlihat dari usaha Dimas Beck yang melanjutkan studinya ke jenjang perkuliahan demi pelunasan hutang kepada orang tuanya.

Berikut ini cuplikan wawancara dan narasi yang menunjukkan perkataan yang mulia:

Narator: Setelah lulus dari sekolah menengah atas atau SMA, Dimas pernah berjanji ke orang tua untuk memprioritaskan kuliah dibanding kegiatan lain. Namun karena tawaran shooting yang datang tanpa henti, niat itu akhirnya batal dan baru terwujud tiga tahun ini. Perkuliahan yang dijalani sekarang menjadi pelunasan utang ke orang tua.

Dimas: "Dulu sebenarnya memang awalnya aku utang sama orang tua, dulu pas abis SMA boleh kerja tapi tetep harus kuliah. Tapi udah keasyikan kerja akhirnya gak kuliah gitu kan. Lalu pada suatu masa, pengen deh kuliah lagi dan akhirnya aku fokus kuliah ."

Penulis mengkategorikan pemberitaan ini ke dalam perkataan yang mulia karena dalam perkataan yang diungkapkan dibarengi dengan rasa hormat, mengagungkan, dan bertata krama karena memang berhubungan dengan orang yang lebih tua dan hal tersebut sangat sesuai dengan indikator dalam pembahasan bab sebelumnya.

Melihat dari pemberitaan tersebut dapat dipetik beberapa pelajaran yaitu pertama, bahwa janji kepada orang tua hendaknya ditepati jika hal tersebut

\section{$114 \mid \begin{aligned} & \text { Islamic Comunication Journal } \\ & \text { Volume 02, nomor 1, Januari-Juni } 2017\end{aligned}$}

menyangkut kepada kebaikan, karena janji harus dilunasi. Dalam hal ini Dimas berjanji menyelesaikan studinya sampai ke jenjang perkuliahan dan pada akhirnya dilaksanakan, hal tersebut merupakan suatu bentuk sikap berbakti kepada orang tua yang bisa dilakukan.

Kemudian, ungkapan qawlan karima juga terdapat pada pemberitaan tanggal 4 Juni 2016 segmen "Jelang Bulan Puasa Para Artis Kunjungi Makam Keluarga”. Penulis mengkategorikan pemberitaan tersebut ke dalam perkataan yang mulia karena gaya bahasa yang digunakan oleh Billy, Dinda, dan Jupe dalam memberikan penyataan terkait dengan orang-orang yang mereka sayangi meskipun telah tiada diutarakan dengan sopan, santun, dalam artian memberikan penghormatan. Seperti Billy yang selalu mendoakan yang terbaik untuk almarhum Olga, Dinda memanggil almarhum ibunya dengan sebutan 'beliau' yang berarti menghormati sebagai sosok orang yang lebih dituakan, begitu juga Jupe yang selalu meluangkan waktu untuk bersilaturahmi ke makam ayahnya, melihat hal tersebut sudah sesuai dengan indikator yang terdapat dalam pembahasan bab sebelumnya.

Hal ini dapat dilihat dari cuplikan wawancara ketiga artis tersebut:

Billy: "Selalu berdoa yang terbaik buat almarhum gitu..........."

Dinda: "....................kayak, beliau kan orangnya sangat-sangat apa ya..sangat bawel gitu lho jadi apa-apa diurusin ama dia gitu, bahkan aku sudah setua ini pun pasti di manajerin tidak tapi di urusin semuanya termasuk kayak makan dan lain-lain,.......” 
Julia Peres: "Eemm..ritual pastinya kalo mau menjelang Ramadhan adalah ke ini ya silaturahmi ke kuburan papa sama adik aku. Paling ya ke Cijantung terus maaf-maafan habis itu udah, langsung menjalankan ibadah puasa.................."

Kemudian, ungkapan qawlan karima juga terdapat pada pemberitaan tanggal 6 Juni 2016 segmen "Cerita puasa di masa kecil Terry Putri dan Alyssa Soebandono". Penulis mengkategorikan pemberitaan tersebut ke dalam perkataan yang mulia karena pernyataan terkait kebiasaan di waktu kecil mereka yang selalu melontarkan pertanyaan-pertanyaan kepada para orang tua mereka dengan tidak berapiapi, dengan bahasa yang santun dan hal tersebut termasuk dalam indikator yang terdapat dalam pembahasan bab sebelumnya.

Hal tersebut dapat terlihat dari kutipan wawancara dengan kedua artis tersebut sebagai berikut:.

Terry: "Hadehh.. masa kanak-kanak emang aku tuh orang Kalimantan ya orang Banjar, jadi memang di sana kan kental banget Islaminya gitu.. jadi kalau dulu tuh di keluarga yang membanggakan itu bukan jadi artis tapi jadi anak yang pinter mengaji atau jadi pegawai negeri itu lebih membanggakan daripada masuk tv buat orang-orang di sana seperti itu... karena mungkin godaan kali ya, karena keIslamanya luar bisa jadi dari jaman aku kecil tuh gak boleh yang namanya ikut model-modelan, pemilihan ini itu gak boleh, pokoknya pulang sekolah les.. ngaji semuanya gitu.. pas maghrib jadi kalau di sana tuh di keluargaku gak boleh di luar rumah kayak begitu tuh gak boleh, apalah ada unsur dari kepercayaan juga macem- macem tapi sebenernya kalau esensi dari Islami emang ya anak perempuan kalau sudah gelap gak boleh di luar rumah aja gitu.. jadi kental banget nuansa keIslamanya sehari-hari aja kental apalagi kalau pas lagi Ramadhan gitu..............."

Alyssa: "Yang jelas Ica itu selalu bertanyatanya karena kan anak-anak diperbolehkan puasa setengah hari, sementara orang dewasa puasa itu puasa full. Nah.. Ica nanya ke mama sama papa, kenapa kok Ica cuma boleh setengah hari kenapa Ica gak full aja.. nahh, akhirnya dibilang gak apa-apa karena masih kecil dan belum baligh jadi perlahanlahan mencobanya dari setengah hari nanti ke full gitu................"

\section{Qawlan Ma'rufan (Perkataan Yang Baik, Pantas)}

Jika ditinjau dari qawlan ma'rufan, ungkapan yang mengandung perkataan yang baik, pantas terdapat pada pemberitaan tanggal 21 Juni 2016 segmen "Pengalaman Menyentuh Dewi Sandra", hal tersebut terlihat pada pernyataan Dewi Sandra serta narasi yang di ucapkan oleh narator terkait kisah orang-orang terpinggirkan.

Berikut ini cuplikan dari wawancara dan narasi terkait pemberitaan tersebut:

Dewi: "Di sini saya dapetin buanyak banget pelajaran-pelajaran tentang kehidupan bagaimana setiap manusia dengan ujiannya masing-masing, emm...berjuang untuk melewati kisah yang sudah ditakdirkan Allah, dan mengajarkan kepadaku secara pribadi bahwa hidup itu memang ibadah dan Allah itu Maha Besar. Allah tidak akan pernah meninggalkan kita, selama kita mau bekerja keras, tetep istiqomah punya semangat. Sebenernya semangat itu dateng dari mana? karena manusia itu pada dasarnya musuh terbesarnya adalah di dalam diri masing-masing ya, rasa malas,

Islamic Comunication Journal Volume 2, Nomor 1, Januari-Juni 2017 
capek, mengeluh dan itu sangat manusiawi sekali. Cuma setiap aku ketemu narasumber, naah ini dia ni yang bikin kita semangat."

Narator: Dalam keseharian, kita sering bertemu mereka yang terpinggirkan yang hidup di pinggir sungai atau di pinggir jalan demi sesuap nasi. Dihadapan mereka kita merasakan kasihan dan iba melihat penderitaan mereka, tapi penilaian itu sebenarnya salah lewat kisah yang di hadirkan Dewi Sandra kita seharusnya mengatakan mereka adalah manusia hebat.

Penulis dapat mengkategorikan pemberitaan tersebut ke dalam qawlan ma'rufan karena sudah jelas tergambarkan dari perkataan diungkapkan Dewi Sandra dan dalam narasi pemberitaanya sesuai dengan indikator yang terdapat dalam pembahasan bab sebelumnya yaitu disampaikan dengan baik dan pantas, dengan mengatakan kekagumannya terhadap orang-orang yang selama ini dianggap hanya sebelah mata ternyata salah, karena pada intinya perjuangan itu memang harus di iringi doa begitu juga sebaliknya doa juga harus disertai dengan perjuangan. Perkataan Dewi juga memberikan pengetahuan, mencerahkan pemikiran, menunjukkan pemecahan terhadap kesulitan kepada orang lemah, jika tidak dapat membantu secara material, hendaknya dapat membantu secara psikologi.

Kemudian, ungkapan qawlan ma'rufan pada pemberitaan tanggal 18 Juni 2016 segmen "Pengalaman Sahur Ekstrim Aliando Syarif”, dan 19 Juni 2016 segmen "Cerita Billy Syahputra Puasa Tanpa Olga".
Penulis mengkategorikan pemberitaan tersebut ke dalam perkataan yang baik, pantas karena kata-kata yang diungkapkan dapat menimbulkan kebaikan (maslahat) hal tersebut sesuai dengan indikator yang ada. Misalnya saja pernyataan Aliando saat belum bisa berkumpul bersama keluarga di bulan puasa karena sibuk shooting, Aliando tetap bersyukur kepada Allah, karena ada hikmah di balik semua rencana Allah. Selanjutnya, Billy dalam pernyataannya tetap berusaha memberikan sebagian rizkinya kepada orang-orang yang membutuhkan. Sehingga secara tidak langsung, pemberian tersebut sangat bermanfaat bagi orang-orang yang membutuhkan.

Hal tersebut dapat terlihat dari cuplikan wawancara berikut ini:

Aliando: ".................. Meski belum bisa kumpul keluarga pas bulan puasa ini ya tetap disyukuri intinya sabar meski capek kan kita kan juga bakal dapat timbal balik yang bener-bener buat hidup juga. Jadi ya jalanin aja karena ini kan cobaan buat kita, insyaAllah setelah bulan puasa ini kita akan menjadi yang lebih baik lagi..............."

Kemudian, ungkapan qawlan ma'rufan juga terdapat pada pemberitaan tanggal 23 Juni 2016 segmen "Rizky Febian Gelar Aksi Sosial untuk Anak-anak Panti Asuhan". Segmen ini memberitakan Rizky Febian yang tengah mengikuti acara bakti sosial untuk anak-anak panti asuhan.

Penulis mengkategorikan pemberitaan tersebut ke dalam qawlan ma'rufan karena dilihat dari narasi yang diucapkan narator dan pernyataan yang dilontarkan oleh Rizky menggunakan kata-kata yang pantas, baik, terkesan mengayomi anak-anak yang 
kurang beruntung karena tidak mempunyai orang tua. Hal tersebut sesuai dengan indikator yang terdapat dalam pembahasan bab sebelumnya, yaitu dapat memberikan manfaat kepada sekitarnya.

Hal tersebut dapat terlihat dari narasi berikut ini:

Narator: Artis yang tengah naik daun Rizky Febian tak melewatkan bulan Ramadhan tanpa berbuat sesuatu yang ia rasa punya manfaat bagi orang lain. Iya, hari minggu kemarin putra komedian Sule ini terlihat ikut terlibat dalam acara bakti sosial yang digelar di sebuah hotel kawasan Jalan Setia Budi Bandung Jawa Barat. Bersama sejumlah pihak lain, pelantun kesempurnaan cinta ini ikut berbagi kebahagiaan dengan sekitar 250-an anak panti asuhan di kota berjuluk Paris Van Java tersebut.

Berikut ini cuplikan wawancara dengan Rizky Febian:

Rizky: "Menurut saya berbagi di bulan Ramadhan kan itu memang bagus, siapa juga si yang gak tau kalau di bulan Ramadhan itu adalah bulan suci, dan benerbener bulan dimana waktunya kita untuk berlomba-lomba mencari pahala yaitu dengan cara salah satunya kayak beramal dan menurut Iky, kebetulan alhamdulillah suatu kebanggan sendiri Iky bisa berpartisipasi di acara amal seperti ini dan ketika Iky dikasih tau acara bakti sosial ini gak pikir panjang, karena menurut Iky ini salah satu pahala juga dan alhamdulillah senengnya di sini bukan cuma menghibur ibu-ibu tapi juga ada anak yatimnya. Jadi menurut Iky pahala itu sangat penting, apalagi di bulan suci Ramadhan jadi buruan kita berlomba-lomba mencari pahala. Karena bulan Ramadhan itu bukan cuma hanya untuk menahan lapar atau menahan hawa nafsu atau apapun tapi bener-bener berlomba. Mumpung sekarang ini bulan
Ramadhan, jadi kita beramal pokoknya gitu lah.. dan menurut Iky jangan cuma pas di bulan Ramadhan saja kita beramal itu juga jadi catatan buat Iky. Sebenernya bulan Ramadhan ini kayak gambaran buat kita untuk berintrospeksi diri supaya setelah bulan Ramadhan buat ke depannya kita harus bisa tetep berperilaku seperti saat di bulan suci Ramadhan kayak gitu sih."

Melihat sikap Rizky Febian yang berbahagia karena bisa berkumpul, berbagi, sekaligus menghibur anak-anak yatim patutlah untuk diteladani. Karena membuat orang lain senang itu merupakan pahala, bahkan sedekah sekecil apapun itu.

Selanjutnya, ungkapan qawlan ma'rufan juga terdapat pada pemberitaan tanggal 28 Juni 2016 segmen "Memiliki Maag Kronis, Aura Kasih Tak Bisa Berpuasa Full". Segmen ini memberitakan penyanyi cantik Aura Kasih yang tidak bisa berpuasa penuh lantaran memiliki penyakit maag kronis. Penulis mengkategorikan pemberitaan tersebut ke dalam qawlan ma'rufan karena dalam bertutur kata termasuk dalam kata-kata baik, sopan, menghormati orang lain sesuai dengan indikator yang ada.

Hal tersebut dapat terlihat dalam narasi dan kutipan wawancara dengan Aura Kasih sebagai berikut ini:

Narator: Rasa antusias aura kasih dengan datangnya bulan suci Ramadhan memang sangat besar. Terlebih ia bisa semakin sering menghadiri dan ikut dalam berbagai acara charity. Bagi Aura bisa bertemu dan menghibur banyak orang merupakan salah satu cara dirinya untuk

\section{Islamic Comunication Journal Volume 2, Nomor 1, Januari-Juni 2017


beribadah dan menambah pahala di bulan yang penuh berkah ini.

Aura: "Gak tau kenapa, emang dari dulu aku suka banget sama acara charity..apalagi hubungannya sama anak-anak kecil, gitu kan..istilahnya selain amal juga ngisi waktu misal lagi gak ada acara apa-apa kenapa sih gak bareng-bareng mereka.. Kan mereka juga seneng dan kita juga seneng.. Jadi ya sama-sama aja, seru. Aku tersentuhnya semangat banget mereka.. Gila, lagi puasa gini kalo orang gede kadang ngerasa lemes..tapi mereka enggak. Karena mungkin melihat ada beberapa temen-temen artis yang ngisi acara, mereka excited banget...terus dari segi keagamaannya mereka juga bagus-bagus, menurut aku mereka generasi muda yang bisa dibanggakan untuk ke depannya..karena menurut aku menghibur orang lain itu siapapun, dalam bentuk apapun itu ibadah. Orang lagi sedih kita hibur, ibadah dong..buat kita juga, dan buat mereka ya juga ada sesuatu yang positif. Dan dari dulu emang aku suka banget menghibur seseorang yang lagi sedih atau apapun deh..aku suka, suka banget."

Melihat sikap Aura yang gemar menghibur orang lain di kala sedang murung patutlah diteladani, karena sebagai manusia sosial seharusnya memang saling tolong menolong sehingga selama hidup di dunia ini dapat menjadi manusia yang bermanfaat bagi manusia lain.

\section{Qawlan Layyina (Lemah Lembut)}

Jika ditinjau dari qawlan layyina, ungkapan yang mengandung perkataan lemah lembut terdapat pada pemberitaan tanggal 14 Juni 2016 segmen "Hijab Ala Umi Pipik". Hal tersebut terlihat saat umi
Pipik menasehati putra-putrinya dengan penuh kasih sayang untuk selalu taat beribadah dimanapun berada.

Berikut ini cuplikan perkataan umi Pipik dalam wawancara:

Pipik: "................Kali ini saya punya target, anak-anak harus khatam qur'an, yuk kita mulai nanti maghrib buka puasa bareng-bareng kalau misalkan saya ada kegiatan shooting live di tv ya anak-anak saya boyong ke sana, terus tarawihnya saya ajakin anak-anak keliling, kita coba ke masjid ini sambil bawa makanan abis tarawih kita bagi-bagi, besok ada ke masjid mana lagi, ada targetnya. Ya saya ajarkan anak-anak seperti itu."

Penulis mengkategorikan pemberitaan tersebut dalam qawlan layyina, karena dalam menuturkan perkataan kepada putraputrinya, umi Pipik menggunakan bahasa yang lemah lembut, dengan suara yang enak didengar, dan penuh keramahan sehingga dapat menyentuh hati dan hal tersebut sesuai dengan indikator yang ada dalam Tabel.

Kemudian, ungkapan qawlan layyina juga terdapat pada pemberitaan tanggal 7 Juni 2016 segmen "Cerita Saipul Jamil Jalani Puasa Pertama di Penjara". Penulis mengkategorikan pemberitaan tersebut ke dalam perkataan yang lemah lembut karena tutur kata yang digunakan santun dan penuh keramahan memenuhi beberapa indikator yang terdapat dalam bab sebelumnya.

Hal tersebut dapat terlihat dari kutipan wawancara dengan Saipul Jamil berikut ini: Ipul: Saya menyadari bahwa ini adalah hak Allah jadi Allah mau kita berpuasa di manapun itu hak Allah.. bisa jadi tahun ini saya di rutan, bisa jadi tahun depan bisa di rumah, atau bisa di

\section{$118 \mid \begin{aligned} & \text { Islamic Comunication Journal } \\ & \text { Volume 02, nomor 1, Januari-Juni } 2017\end{aligned}$}


tanah suci atau bisa jadi tidak ada gitu.. paling kita sebagai manusia harus siap, tapi tetep sekali lagi kita harus berdoa yang baik-baik kepada Allah.. mudah-mudahan dijauhkan dari orang-orang yang ingin berbuat dzalim yang berbuat jahat gitu pada saya..........................."

\section{Qawlan Maisura (Mudah Diterima)}

Jika ditinjau dari qawlan maisura, ungkapan yang mengandung kata-kata mudah diterima terdapat pada pemberitaan tanggal 5 Juni 2016 segmen "Persiapan Selebriti Menyambut Bulan Suci Ramadhan", hal tersebut terlihat saat pasangan selebriti Teuku Wisnu dan Shireen Sungkar menyebutkan dalam menyambut puasa di bulan Ramadhan mereka melakukan pemanasan seperti puasa sunah terlebih dahulu seperti yang diajarkan oleh guru mereka.

Berikut ini cuplikan
wawancara dengan pasangan
selebritis tersebut:

Wisnu dan Shireen: "Kalau persiapan Ramadhan ya fisik, karena yang saya pelajari dari guru kita memang harus ada pemanasan lebih dulu, dalam arti ada puasapuasa sunah yang mungkin kita lakukan sebagai pemanasan untuk menuju bulan Ramadhan. Persiapan fisik ya kita juga harus jaga kesehatan kita, jaga juga diri kita karena pada bulan Ramadhan inilah saatnya umat Islam berlomba-lomba untuk mencari pahala sebanyak-banyaknya, melakukan amalan sebesar-besarnya, jadi gitu yang selama ini saya pelajari."

Melalui pernyataan yang diungkapkan pasangan selebritis tersebut, penulis mengkategorikan pemberitaan ini termasuk dalam perkataan yang mudah diterima karena Wisnu dalam melontarkan pernyataannya menggunakan bahasa yang ringan, sederhana, secara spontan tanpa harus melalui pemikiran yang berat dan hal tersebut sesuai dengan indikator yang terdapat dalam Tabel.

\section{PENUTUP}

Setelah menguraikan tentang pembahasan dan analisis sesuai dengan pokok-pokok permasalahan yang diangkat dalam skripsi ini yang berjudul "Program Infotainment Ditinjau dari Etika Komunikasi Islam (Analisis terhadap Insert Siang di TRANS TV Edisi Bulan Ramadhan $1437 \mathrm{H}$ )" maka penulis menarik kesimpulan bahwa tidak semuanya pemberitaan dalam program infotainment Insert siang bermuatan baik, pemberitaan mengenai permasalahan pribadi para artis lebih dominan seperti halnya konflik rumah tangga, kehidupan asmara, kawin-cerai dan lain sebagainya.

Tetapi terlepas dari itu semua, tidak melulu infotainment Insert siang memberitakan hal buruk, hal tersebut terlihat dari perolehan angka sebesar 82 persen dari rata-rata total keseluruhan pemberitaannya khususnya pada bulan Ramadhan yang menunjukkan pemberitaannya sesuai dengan etika komunikasi Islam menurut Jalaluddin Rakhmat yang menyebutkan ada enam bentuk perkataan (qawlan) sesuai al-Qur'an yaitu (qawlan sadidan) sebesar 14 persen, (qawlan baligha) sebesar 18 persen, (qawlan karima) sebesar 11 persen, (qawlan ma'rufan) sebesar 18 persen, (qawlan layyina) sebesar 7 persen dan (qawlan maisura) sebesar 14 persen. 


\section{DAFTAR PUSTAKA}

AGB Nielsen Media Reserch, "Menuju Pengukuran Iklan Non-Klasik”, dalam Jurnal AGB Nielsen Newsletter, Edisi 34, Juni, 2009.

Santosa, Hedi Pudjo. 2011. Menelisik LikaLiku Infotainment di Media Televisi. Yogyakarta: Gapai Asa Media Prima.

Taufik, Tata. 2012. Etika Komunikasi Islam. Bandung: CV Pustaka Setia.

Rakhmat, Jalaluddin. 1994. Islam Aktual: Refleksi Seorang Cendekiawan Muslim. Bandung: Mizan.

AC Nielsen. 2011. "Newsletter Februari", dalam

www.agbnielsen.net/Uploads/.../Nie

1sen_Newsletter_Feb_2011-

Ind.pdf., diakses 5 Oktober 2016.

S, Alaik. 2011. 40 Hadits Shahih Bibirmu Harimaumu. Yogyakarta: Pustaka Pesantren.

Djamarah. Bahri, Syaiful. 2004. Pola Komunikasi Keluarga Orang Tua dan Anak dalam Keluarga. Jakarta: PT Rineka Cipta.

An-Nawai, Imam. 2014. Syarah Ringkas Riyadhus Shalihin terj. Thariq Abdul 'Aziz At-Tamimi dan Hamzah Amali. Jakarta: Pustaka As-Sunnah.

\section{Syarah Shahih} Muslim terj. Wawan Djunaedi Soffiandi. Jakarta: Pustaka Azzam.
. 2011. Syarah Shahih Muslim terj. Ahmad Khatib. Jakarta: Pustaka Azzam. . 2013. Mutiara Riyadhus Shalihin terj. Ahmad Rofi' Usmani. Bandung: Mizan.

Ardianto, Elvinaro. Komala, Lukiati. Karlinah, Siti. 2009. Komunikasi Massa Suatu Pengantar. Bandung: Simbiosa Rekatama Media.

Badjuri, Adi. 2010. Jurnalistik Televisi. Yogyakarta: Graha Ilmu.

Baqi, Muhammad Fu'ad Abdul. 2014. Mutiara Hadits Shahih BukhariMuslim terj. Arif Rahman Hakim. Solo: Al-Andalus.

Budiono. Kamus Lengkap 300 juta InggrisIndonesia Indonesia-Inggris. Surabaya: Alfa Perc. 